\title{
TOURISM AND TERRORISM: THE CASE OF BULGARIA
}

\author{
H. Dobreva* \\ Faculty of Engineering and Pedagogy-Sliven, Technical University Sofia, Bulgaria
}

\begin{abstract}
Tourism is one of the most vulnerable areas of economics affected by terrorism. It poses international and national security issues. The paper starts by defining the two concepts. After 9/11 the influence of terrorism on tourist travelling increases. That demands new measures for security provision in the tourist sphere. The most important question is how to predict vulnerability in the area. The paper presents a matrix that depicts the linkage between crime and tourism, and examines the relationship between the two. Then the focus shifts to the case of Bulgaria and its terrorism vulnerability because of factors as geographic location, religious fanaticism and illegal immigration as security threats. Bulgaria is an external EU border and that fact determines both the challenge and the obligation for more responsible and viable security provision. The mentioned matrix is applied to the case of Bulgaria as more space is devoted to the example of the Burgas terrorist act with Israeli tourists in 2012. The paper ends with suggestions for possible practical measures to be included in the existing strategy for sustainable development of tourism in Bulgaria 2014-2030.
\end{abstract}

Key words: National security, terrorism, tourism

\section{INTRODUCTION}

Terrorism has appeared in the Middle Ages and it has manifestations since the $16^{\text {th }}$ century (8). It is a modification of war, aiming to ruin whole economies by causing casualties and panic with violent means. The targets are whole groups of people rather than individuals or leaders. The nature of tourism is just the opposite of that of terrorism. Tourism belongs to modernity in its technical sense. Tourism is the most modern industry -mass and leisure tourism has appeared only after WW2. Before that tourism has been associated mostly with work, and the proof is in the etymology of the English word "travel", derived from the French "travail" (work), derived in turn from the Latin word for "pitchfork" (8). The terrorismtourism relationship may be described with the help of a terrorism-tourism matrix-a matrix applied to the Bulgarian case of terrorism in the tourist industry of 2012.

After September 11, tourism industries have been damaged throughout the world (8). The

\footnotetext{
*Correspondence to: HRISTINA DOBREVA, Technical University Sofia-Faculty of Engineering and Pedagogy-Sliven, Bulgaria, "Druzba", bl. 20, ent.2, apt.10, Sliven 8800, Bulgaria, Tel: +359899 108 715,e-mail:n_hris@yahoo.com
}

question of tourism security and its integration into a strategic marketing plan have become apparent. Obviously the screening processes typical for air travel have not prevented the occurrence of the Bulgarian case that happened at the airport-not before but after the air travelling. The strange behavior of tourists (the attacker also being a tourist) has not been observed through the prism of terrorism. The traditional image of the state as an island of stability or a safe country for tourists may have lessened the sharpness of attention of Bulgarian authorities.

\section{THEORETICAL BACKGROUND 1.1. DEFINITION OF THE CONCEPTS TERRORISM AND TOURISM \\ 1.1.1 TERRORISM}

Terrorism exhibits some social characteristics inherent to the so called "medieval societies" (8), pertaining to any historical period. The first characteristic is the lowering of the status of women, the second-the xenophobic fear or hatred towards the "other", the third-the insecurity and henceforth difficulty of travelling, the forth-rejection of the capitalist economic order and its replacement with an Islamic economic system (capitalist gain is "unholy" and Islamic "gain" is sought in the afterlife), the fifth-rejection of individualism as 
opposed to inherited or assigned posts (the group is more important than the individual).

The terrorism's longing for the bygone days is called "restorative nostalgia" (8). The latter can become the motor of terrorism with its focus on tradition and symbols, protection of the absolute truth, with its national and linear memory, with its restoration of national origins and conspiracy theories. In other words restorative nostalgia belongs to the past as opposed to reflexive nostalgia that belongs to modernity and the future.

Terrorism has a huge negative economic impact (2). The term can be defined as "any premeditated, politically motivated violence perpetrated against non-combatant targets by sub-national groups or clandestine agents, usually intended to influence an audience" (2). Usually terrorism involves victims or targets (institutions, governments, citizens) of more than one country and that makes it a transnational phenomenon. Terrorism's aftermath may be characterized (1) with the help of the following features of the acts: forceful attack on civilians, unofficial (not belonging to any nationality) character of the attack, achievement of political or economic goals, desire to achieve far-reaching effects with the help of the media.

\subsubsection{TOURISM}

Tourism exhibits characteristics inherent for the modern societies: the involvement and predomination of women in the industry, opposition to xenophobia, stimulation of travelling and diversity, collaboration with capitalism, focus on openness and individual attention in the provision of the service. Paradoxically these features, opposite to terrorism, make tourism a more vulnerable target for unprecedented attacks of all kinds. Since tourism holds the "nation's iconic treasures" (8), an attack on tourism is not only an attack on the economy but also an attack on those treasures. Since national treasures are part of the world cultural treasures and national economies participate in the operation of the world economy, attacks on them may be accepted as world terrorist attacks.

Tourism is the most important contemporary industry (2), the leading economy of the $21^{\text {st }}$ century. The total sales revenue and the number of travelers have been vastly increasing. The industry is yielding 10,2 percent of the world's gross national product.

\subsection{THE RELATION BETWEEN TERRORISM AND TOURISM: DIFFERENCES AND COMMONALITIES}

As the $21^{\text {st }}$ century faces tourism as the leading economy, it also faces terrorism as the leading threat. There is nothing accidental in the linkage between the two (8). First, the existence of terrorist acts in the tourist industry has existed for a long time. However modernity and globalization have made possible the intensification of acts against civilians.

There have been certain aspects that increase tourism's vulnerability to terrorism (8): 1) the nature of the tourist product-its volatility, capriciousness, openness, make it an easy target, 2) the reaction to terrorism produces an "opportunity-lost" phenomenon (terrorism warnings/reactions are a secondary form of terrorism), 3) the reaction relies on fearproduction that is triggered by the media, 4) the nature of the clients in the industry-tourists are not easy to track and they are anonymous (hence they are both sources and targets of terrorists), 5) the nature of the industry's operations-its connection with major transportation centers (henceforth with the economy), 6) the publicity sought by the tourist industry through the media serve terrorists' publicity and mass impact. Tourism may be both a target and a cover for terrorist acts. The number of deaths caused by terrorism has been increasingly rising though the number of attacks has not been that shocking.

As a major economic industry, an attack on tourism has a highly negative impact on the whole economy (2). Economic consequences will involve the decrease of the number of tourists caused by the triggered fear (psychological reasons) and a negative image of the industry caused by the spread of mass communication (the transnational character of the act increases the world press coverage). Economic consequences reflect on the state as a whole-an attack on the economy is an attack on the whole state.

Despite the fact that they embody opposite philosophies, there are at least two common features between terrorism and tourism (4): 1) the same processes-globalization and technological innovations-have triggered both the tourism's growth as an industry and terrorism's growth as a threat (both benefit from mass transportation, modern technology, communications), 2) media serves both through the projection and manipulation of beliefs and perceptions (media persuasion serves both tourism and terrorism marketing, achieving economic profit in the first case and demoralization of the opponent/flow of funds and recruits in the second). Strangely yet terrorist sites can attract visitors and become a 
source for the so called "dark tourism". Despite the negative effects on tourism, the industry is surprisingly adaptable.

\subsection{THE CRIME-TOURISM MATRIX AND THE TERRORISM-TOURISM MATRIX}

Terrorism differs from traditional forms of crime (8). First of all tourism crime is a form of a business (tourism criminals flourish in a successful tourist industry), while tourism terrorism is a form of ideology that aims at the destruction of industries, nations, governments, economies. Secondly, while crime achieves local publicity, terrorism achieves international publicity. Thirdly, while crime has short term negative effects, terrorism has long term negative effects. Fourthly, while both target tourists and tourist destinations, the relationship crime-tourism may be accidental and the relationship terrorism-tourism is planned in most of the cases or almost always (6).

Table 1. The Crime-Tourism Matrix

\begin{tabular}{|l|l|l|}
\hline & $\begin{array}{l}\text { The tourist as an incidental } \\
\text { victim }\end{array}$ & $\begin{array}{l}\text { The tourist as a deliberate } \\
\text { victim }\end{array}$ \\
\hline Inherent touristic values & $\begin{array}{l}\text { Cell 1 } \\
\text { Self-indulgent, Loosening of } \\
\text { responsibility } \\
\text { Type 4 }\end{array}$ & $\begin{array}{l}\text { Cell } 2 \\
\text { Relaxed, Off guard, Leisure } \\
\text { oriented } \\
\text { Type 3 }\end{array}$ \\
\hline Extrinsic touristic values* & $\begin{array}{l}\text { Cell 3 } \\
\text { Open access, ease of movement } \\
\text { Type1, 2 }\end{array}$ & $\begin{array}{l}\text { Cell 4 } \\
\text { Threat to national culture, } \\
\text { perceived as a threat } \\
\text { Type5 }\end{array}$ \\
\hline
\end{tabular}

*Extrinsic factors refer to non-tourist systems present within the tourist zone. Source: Ryan, 1993

Second, the terrorism-tourism relationship may be described with the help of the terrorismtourism matrix (Table 2) that also classifies five types of relationships. The five types show combinations of criminal/political terrorism on the one hand and systematic/random terrorism on the other hand.

Usually terrorism is divided into political or criminal and individual or collective (3). Political terrorism is the most widely observed and it targets political systems even through a secession of a territory from the sovereign state (type 1,2 and 5). On the other hand, criminal terrorism is less complex and considers financial reasons (type 3 and 4). Terrorism can negatively influence the whole economic system since tourism is connected with spatial development, infrastructure, foreign investments (type 3). All types may include several methods of attack: bombing (most widely used), kidnapping (of vehicles or people to use as bargaining tools in
First the crime-tourism relationship may be described with the help of the crime-tourism matrix that classifies five types of relationships (6) (Table 1): 1) Type one is when tourists are incidental victims and the crime does not depend on the tourist destination but may happen in non-tourist areas (targeted at the indigenous population), 2) Type two is when the crime depends on the tourist location/activities but the targets are not only tourists, 3) Type three is when tourists are easy targets (or also perpetrators of the crime) in an unorganized act of small, opportunistic groups aiming to achieve economic gains (acquisition of property), 4) Type four is when there is an organized criminal activity as a response to a tourist demand, 5) Type five is when there is a combination between an organized criminal/terrorist groups and violence on tourist/tourist facilities. In the latter case terrorism motivates its actions with terrorists' perceptions that tourists are symbolic of rich, capitalist countries, and that state-supported tourism is symbolic of governments. 
pluralism as typical for the western lifestyle. When states' response to terrorism resembles that of a military threat (type 5), the perception increases the cost of the response.

Table 2. The Terrorism-Tourism Matrix

\begin{tabular}{|l|l|l|}
\hline & $\begin{array}{l}\text { The tourist as an incidental } \\
\text { victim }\end{array}$ & The tourist as a deliberate victim \\
\hline Inherent touristic values & $\begin{array}{l}\text { Cell 1-Random terrorism-criminal } \\
\text {-criminal (economic) terrorism } \\
\text {-suicide bombing (accidental } \\
\text { deaths) } \\
\text { Type } 4\end{array}$ & $\begin{array}{l}\text { Cell 2-Systematic terrorism- } \\
\text { criminal } \\
\text {-criminal terrorism } \\
\text {-kidnapping } \\
\text {-bombing } \\
\text {-against western lifestyle } \\
\text { Type 3 }\end{array}$ \\
\hline Extrinsic touristic values & $\begin{array}{l}\text { Cell 3-Random terrorism-political } \\
\text {-aimed at the vulnerable } \\
\text {-destruct the political order } \\
\text { Type1, 2 }\end{array}$ & $\begin{array}{l}\text { Cell 4-Systematic terrorism- } \\
\text { political } \\
\text {-political terrorism (political } \\
\text { ideology) } \\
\text {-criminal } \\
\text {-aimed at territory } \\
\text {-terrorism as a military threat } \\
\text { Type5 }\end{array}$ \\
\hline
\end{tabular}

\section{TERRORISM AND THE CASE OF BULGARIA}

\subsection{THE POST SEPTEMBER 11 PARADIGM AND THE BULGARIAN CASE: TERRORISM-TOURISM MATRIX APPLIED}

There is no clear-cut distinction in terms of allocating the Bulgarian case in a single cell of the matrix. The case possesses elements of all four cells of the matrix (Table 3). Cells one and two describe cases where the target is the Bulgarian tourism industry as a vulnerable industry. Bulgarian tourism is the major source of revenue for the economy. That is why destructing tourism will cause major detriments to the whole economy. Bulgaria's difficult economic situation and unemployment are generally seen as a positive environment for the occurrence of crimes.

Cell 1 points out at one possibility-the act to be a case of a suicide bombing which has not been concluded with certainty yet. Cell 3 focuses on the nature of the performance of the act which cannot be predicted and can happen anywhere. Both cells 2 and 4 describe cases of deliberate (planned) actions of a terrorist organization (Hezbollah). The act in both cells is part of the post September $11^{\text {th }}$ plot and has a certain pattern of execution from a network of terrorist organizations. The act can be targeted at the Israeli state (scattered nature of the state) where the act against one citizen is perceived as an act against the state as a whole. The fact that the Bulgarian territory is used as the place of the attack and the information about Hezbollah working in Cyprus for plotting a similar attack outline a possibility where Europe as a whole may be accepted as a target. The latter may be a result of the European involvement in Syria and the war on terror.

Europe may be considered as the target of the plot since tourism is an economic activity that has a potential to generate future growth and occupation in the EU (5). Tourism brings between $2 \%$ and $12 \%$ GDP growth in the EU. At the same time tourism is the opposite of war and it can develop only under peaceful conditions and stability (5).

Table 3. Terrorism-Tourism matrix: the Bulgarian case

\begin{tabular}{|c|c|c|}
\hline & $\begin{array}{l}\text { The tourist as an incidental } \\
\text { victim }\end{array}$ & The tourist as a deliberate victim \\
\hline Inherent touristic values & $\begin{array}{l}\text { Cell 1-Random terrorism } \\
\text { A suicide bombing aimed at the } \\
\text { Bulgarian tourist industry causing } \\
\text { accidental deaths } \\
\text { Type } 4\end{array}$ & $\begin{array}{l}\text { Cell 2-Systematic terrorism } \\
\text { Planned action of a terrorist } \\
\text { organization aimed at the tourist } \\
\text { industry and the whole economy } \\
\text { (part of the post sept. } 11 \text { paradigm) } \\
\text { Type } 3\end{array}$ \\
\hline Extrinsic touristic values & $\begin{array}{l}\text { Cell 3-Random terrorism } \\
\text { Unpredictable terrorist act that can } \\
\text { happen anywhere } \\
\text { Type1, } 2\end{array}$ & $\begin{array}{l}\text { Cell 4-Systematic terrorism } \\
\text { Planned action of a terrorist } \\
\text { organization aimed at Europe or the } \\
\text { Israeli state (part of the post sept.11 } \\
\text { plot) } \\
\text { Type5 }\end{array}$ \\
\hline
\end{tabular}


Bulgarian authorities have acted optimistically to the post September 11 paradigm-similarly to futuristic experts. Experts on future scenarios (2) mostly believe in the development of the globalization age $(35 \%)$ that predict the increase of the tourism industry and the burst of new markets like China and India. ${ }^{1}$

This means that there is no integrated response among the countries regarding the post September 11 paradigm. For example while 9/11 has increased American patriotism (targets or American citizens united in their response), the Buenos Aires bombing has increased social fragmentation and isolation of the victims-the Jewish community being perceived as a risk (4). The best response is when the tourism crisis after the event leads to an enhancement, to mustering of a new opportunity, to acquiring a new competitive advantage.

During the past-in the 80s, according to some authors (7) Bulgaria has been considered itself a terrorist state (providing weapons, supplies, financing, coordination and training to terrorists) together with countries from the communist bloc and the USSR. However in the 90s those countries have changed to Iran, Iraq, Libya, North Korea, Sudan, and Syria.

The Bulgarian case has happened in July 2012 when after a bus explosion outside the Burgas airport, Israeli tourists and their Bulgarian driver (a Muslim) have been killed (14). Following the established path of perceptions Israeli politicians have blamed Iran (or other radical Muslim group as Hezbollah or Hamas) as an attacker with no proof soon after the event. From the beginning the perception has been that the targets are the Israelis and the location (Bulgaria) has been selected only

1 The futurist Matthias Horx developed four different scenarios (Herdin). On the one axis he focussed on the probability of the anti-terror coalition intensifying or collapsing, on the other axis he positioned the terrorist activities (increasing-decreasing). Crossing these axis he extracted four possible scenarios, the jihad age, separation prosperity, globalisation plus and security age. $31 \%$ of the respondents believe that security will be an important issue in the tourism industry and safet checks and security personnel have to increase. $19 \%$ of the interviewees face a separation of rich and poor countries. International tourism will decrease while domestic tourism increases. Only $15 \%$ of the experts expect the worst case scenario, the jihad age. In context of tourism this would lead to a breakdown of the tourism industry. Business travel and visiting relatives would be the only tourist activities. because the country is a popular destination for Israeli tourists. So the plot has been placed into the pattern of international terroristic plots. Some analysts have mentioned that Israel has warned Bulgarian authorities about the possibility of a terrorist attack on Israelis, which also points at the direction of dealing with an organized plot. There has also been an established coincidence-the act has happened on the 18th anniversary of an attack on a Jewish community center in the Argentinian capital, Buenos Aires. The reason for the attack may have been the increased tension between Iran and Israel as a result of Iran's program for developing nuclear weapons. Israel which is also believed to possess nuclear weapons has threatened to attack Iran and stop its program.

Bulgaria has reacted to the act with caution. The authorities have demanded the help of Europol in the investigation (12). The analysis has suggested that the act has been carefully planned with a remote detonation and a small group involved (instead of being just an act of a suicide bomber). European experts have pointed to the existence of a possible link to Hezbollah- a Shiite movement. Bulgarian authorities have been reluctant to specifically name the exact perpetrators as proof is insufficient to point at Hezbollah. The United Kingdom and the Netherlands have been the two European partners that have pressed for the inclusion of that terrorist movement on the list of terrorist groups (9). However, media in the country has sent mixed messages about the conclusion of the investigation. For example on February 5, 2013, a Bulgarian authorities' report has been cited with the results of the investigation. It indicates that Hezbollah's military wing has planned and performed the attack but has no mention of Iran (17). The media in the country is gullible in covering the act. Both the media and the country itself have not been prepared for the "war on terror" and the new post September 11 normalcy (10). The security system in Bulgaria has been questioned as lacking a special system for protecting Israeli tourists. The media has paid no attention to the fact that Bulgarian Muslim community lives in peaceful coexistence with the Bulgarian population.

\subsection{LESSONS LEARNT AND POSSIBLE PRACTICAL MEASURES}

Airports and buses in the Bulgarian case have proven to be highly open structures (like hotels). The attack questions the safety of the Israeli community in Bulgaria although the country is famous with saving its Jews during the WW2. Thus it can be argued that the act 
has negative implications on a long-established relationship which Bulgaria is proud of- a part of its national iconic treasures. The security policy should be preventive rather than reactive (dealing with the aftermath of the event) because in the latter case it involves more resources.

Bulgaria's geographic location (near places where religious fanaticism grows) and the threat of potential illegal immigrants make it more vulnerable to terrorism (13). Bulgarian security investments are made generally by the state but they are not focused specifically on tourism's security. It has been even more difficult for the state to react to threats because so far the EU has not yet defined its common defence strategy and policy. Bulgaria is an external border to the EU and thus its security provision is more specific. In the sphere of tourism, as the Balkan region is viewed as a whole, the message should be that the region is safe as a whole. Bulgaria is also still not a part of the Schengen mechanism that will possibly increase its security level.

There is no exact formula to predict terrorist attacks (8) but a careful analysis should consider: 1) the site's potential for mass casualties, 2) the location's potential for offering mass publicity and good images for the media, 3) the site's relation to the economy, 4) the site's contents-whether it has a national iconic value. These features have to become a part of a risk management preventive policy, based on what may happen rather than on what has happened. The latter is a nonpolicy and is inherent to poor planning and marketing. A security analysis should start by listing weaknesses and vulnerabilities, developing "a working relationship" (8) between local security authorities and the industry, developing security pamphlets and signs (with evacuation routes, people and things to avoid, emergency access phones and numbers).

International standards and laws are unsuitable to the situation (3). For example the most important organization dealing with the prevention of terrorism in tourism-the World Tourism Organization (called the United Nations World Tourism Organization, UNWTO) has been mostly dealing with sustainable development of tourism in the implementation of its "Global Code of Ethics for Tourism" (a voluntary agreement in itself). The current strategy for sustainable development of tourism in Bulgaria (15) does not mention the terrorist threat. Terrorism has only been mentioned as a crisis phenomenon (like war and natural disasters) which according to data from the World Tourist Organization has not affected the annual growth of international touristic travelling and the annual income from tourism. Bulgaria has experienced an average annual growth of incoming tourism higher than the average for the sub-region of Central and Eastern Europe. Asia is anticipated to be the fastest growing region for incoming tourism. The strategy is defined in the document as a "constellation of norms" which influences the decision-making and the future state of the tourist sector, including as a medium for connecting with the external environment. It is a general action program that uncovers the priority problems and resources for achieving the main purposes.

European terrorism faces especially the threat of radical Islamic violence which has increased with one third across the continent according to Europol (16). The report considers Bulgaria together with Bosnia and Herzegovina as "some of the riskiest areas » because of the existence of large muslim communities in both countries. The report connects Hezbollah with the Bulgarian case and also with money laundering in Cyprus and Belgium. European terrorism has witnessed also the emergence of "lone-wolf attacks" of religiously radicalized young individuals. The new form of attacks is less predictable and avoidable. The prevention of terrorism involves the application of deradicalization programs throughout Europe including for example education and integration.

As a result of the terrorist act in Burgas the EU has declared Hezbollah's military wing as a terrorist organization (18). Bulgaria has increased security measures for Israeli tourists and has planned to develop an anti-terrorism centre under the State Agency for National Security. Despite that a part of the Bulgarian public still refuses to accept the "new normalcy" (10) of a constant fear of a terrorist threat. Nobody in the country wants to turn Bulgaria into a great power game's pawn once again.

The EU has blacklisted as a terrorist organization the military wing of Hezbollah, the Lebanese Shiite group (11) both because of its participation in Europe-based bombings and because of its role in the Syria war. That has been a symbolic act showing an unanimous EU response to a common threat. The Bulgarian act has been accepted as an act on European territory/soil and a similar attack has been said to be plotted by the group in Cyprus. 


\section{CONCLUSION}

In their nature terrorism and tourism have opposite characteristics. Terrorism belongs to the medieval age and tourism belongs to modernity. Some aspects of tourist industry make it vulnerable to terrorist acts. The same processes and role of the media affect both terms however.

Only one cell of the crime-tourism matrix depicts the relation between the two as a threat from an organized terrorist group. The terrorism-tourism matrix describes cases of both random and systematic terrorism and of both political and criminal terrorism. The Bulgarian case has characteristics inherent to all cells of the matrix, depending on the starting point. Future security policy in the tourism sphere should be preventive and take into consideration the location of the country, its belonging to the $\mathrm{EU}$, the cooperation among state institutions, the co-existence of different ethnic communities in the country, the postSeptember 11 terrorism paradigm. These aspects should all be included in the strategy for sustainable development of tourism in Bulgaria.

\section{REFERENCES}

1. Frey, B. and S. Luechinger. Measuring Terrorism, October, Working Paper No. 171, Institute for Empirical Research in Economics University of Zurich, Working Paper Series, 2003

2. Herdin, T. Tourism and Terrorism, The Tourism Industry: a Perfect Target for Terrorist Activity, p.61-72 in The Wicked Heart, Studies in the Phenomena of Evil ed. By Sorcha Ní Fhlainn \& William Andrew Myers, Inter-disciplinary press, Papers Presented at the Sixth Global Conference on Evil and Human Wickedness, Prague, Czech Republic, March 2005

3. Kachmarska, A. Terrorism as Threat to International Tourism, Visnyk of the lviv University. Series international relations. Issue 34. p. 187-196, 2014

4. Korstanje, M. and A. Clayton. Tourism and terrorism: conflicts and commonalities, Worldwide Hospitality and TourismThemes, Vol. 4 No. 1, pp. 825, Emerald Group Publishing Limited, 2012, www.emeraldinsight.com/17554217.htm

5. Krasteva, V. and others (no year). Introduction to Tourism, "Dimant", (Въведение в туризма, В. Кръстева и други, „Димант”)

6. Ryan, C, Crime, violence, terrorism and tourism, An accidental or intrinsic relationship?, Butterworth-Heinemann Ltd, Tourism Management, June 1993

7. Sönmez, S. Tourism, Terrorism and Political Instability. Annals of Tourism Research, 25(2):416, 1998, Made available courtesy of Elsevier: http://www.elsevier.com/

8. Tarlow, P., Ch.6 Terrorism and Tourism, p.79-92 in Tourism in Turbulent Times, Towards Safe Experiences for Visitors, ed. by Jeff Wilks, Donna Pendergast and Peter Leggat, Advances in Tourism Research Series, Elsevier Ltd., 2006

9. A year after terrorist attack in Burgas: question marks remain, published on 7/18/13, http://bnr.bg/en/post/100206274/a-yearafter-terrorist-attack-in-burgas-questionmarks-remain

10. Bulgaria bombing catches country unprepared, Mariya Petkova, 31 Jul 2012, http://www.aljazeera.com/indepth/opinion /2012/07/20127308251786378.html

11. European Union Adds Military Wing of Hezbollah to List of Terrorist Organizations, By James Kanter and Jodi Rudoren, July 22, 2013, http://www.nytimes.com/2013/07/23/worl $\mathrm{d} /$ middleeast/european-union-addshezbollah-wing-to-terrorlist.html?pagewanted=all\&_r=1\#

12. Europol supports investigation into terrorist attack at Burgas airport, Bulgaria The Hague, the Netherlands 5 February 2013, https://www.europol.europa.eu/content/eu ropol-supports-investigation-terroristattack-burgas-airport-bulgaria

13. Events and News, Conference "The threat of terrorism and crime in tourism from the view point of the politics of the European Union", March 19 2010, Sofia (Събития и новини, Конференция «Заплахата от тероризъм и престьпността в туризма от гледна точка на политиката на Европейския съюз», 19 март 2010 г., София.,) http://asbg.bg/?cid=8\&NewsId $=6$

14. Israelis killed in Bulgaria bus terror attack, minister says, By the CNN Wire Staff, July 19, 2012, http://edition.cnn.com/2012/07/18/world/e urope/bulgaria-israel-blast/

15. Strategy for sustainable development of tourism in Bulgaria 2014-2030, Sofia May 2014, Ministry of economics and energetic (Стратегия за устойчиво развитие на туризма в България 20142030 , София Май 2014г. , Министерство на икономиката и 
енергетиката),

http://www.tourism.government.bg/sites/t ourism.government.bg/files/uploads/strate gy-policy/strategy_20142030_13_05_2014sled_ms_26_05_2014.pdf

16. Terrorism in Europe: US and Europol reports unveil an ever-expanding galaxy, Gianluca Cesaro, 7 juin 2013, http://europe-liberte-securitejustice.org/2013/06/07/terrorism-ineurope-us-and-europol-reports-unveil-anever-expanding-galaxy/

17. The Meir Amit Intelligence and Terrorism Information Centre at the Israeli
Intelligence \& Heritage Commemoration Centre, February 8, 2013, Comments on the report issued by Bulgaria about the terrorist attack in Burgas, http://www.terrorism-

info.org.il/Data/articles/Art_20474/E_029 _13_753532921.pdf

18. Two years on from the terrorist attack on Israelis at Bourgas Airport, justice is still pending, Written by Clive Leviev-Sawyer on July 17, 2014, The Sofia Globe, http://sofiaglobe.com/2014/07/17/twoyears-on-from-the-terrorist-attack-onisraelis-at-bourgas-airport-justice-is-stillpending/ 